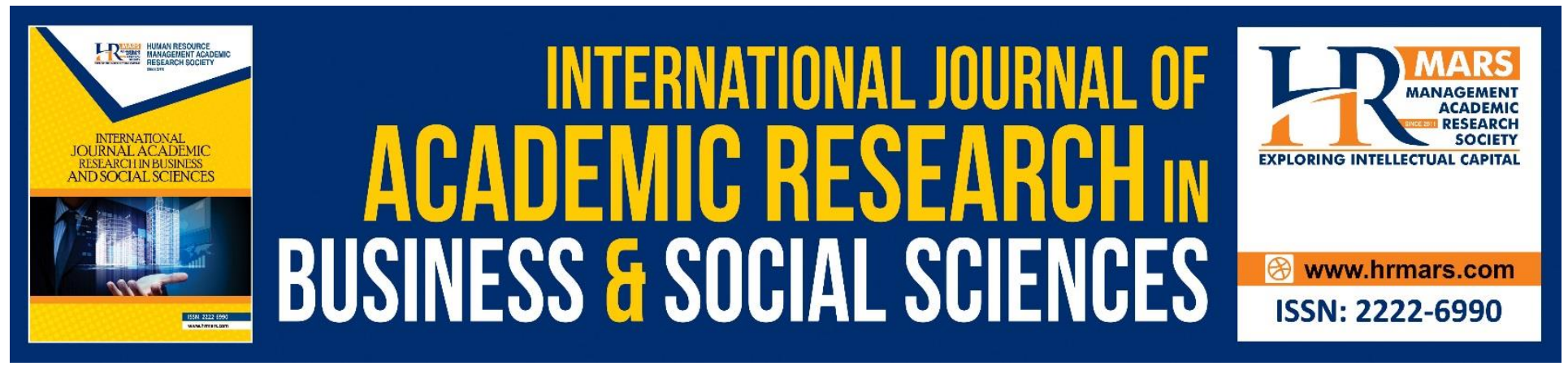

\title{
The Understanding of Mainstream Teachers on the Implementation of the Semi-Inclusive Program in the Curriculum for Special Education (Dyslexia)
}

Shahrul Rozaina Binti Jelani, Mohd Mokhtar Bin Muhamad, Umi Kalthom Abdul Mana

To Link this Article: http://dx.doi.org/10.6007/IJARBSS/v10-i10/8044

DOI:10.6007/IJARBSS/v10-i10/8044

Received: 06 August 2020, Revised: 08 September 2020, Accepted: 30 September 2020

Published Online: 03 October 2020

In-Text Citation: (Jelani, Muhamad, \& Abdul Mana, 2020)

To Cite this Article: Jelani, S. R. B., Muhamad, M. M. B., \& Abdul Mana, U. K. (2020). The Understanding of Mainstream Teachers on the Implementation of the Semi-Inclusive Program in the Curriculum for Special Education (Dyslexia). International Journal of Academic Research in Business and Social Sciences. 10(10), 9981008.

Copyright: (c) 2020 The Author(s)

Published by Human Resource Management Academic Research Society (www.hrmars.com)

This article is published under the Creative Commons Attribution (CC BY 4.0) license. Anyone may reproduce, distribute, translate and create derivative works of this article (for both commercial and non-commercial purposes), subject to full attribution to the original publication and authors. The full terms of this license may be seen at: http://creativecommons.org/licences/by/4.0/legalcode

Vol. 10, No. 10, 2020, Pg. 998 - 1008

Full Terms \& Conditions of access and use can be found at http://hrmars.com/index.php/pages/detail/publication-ethics 


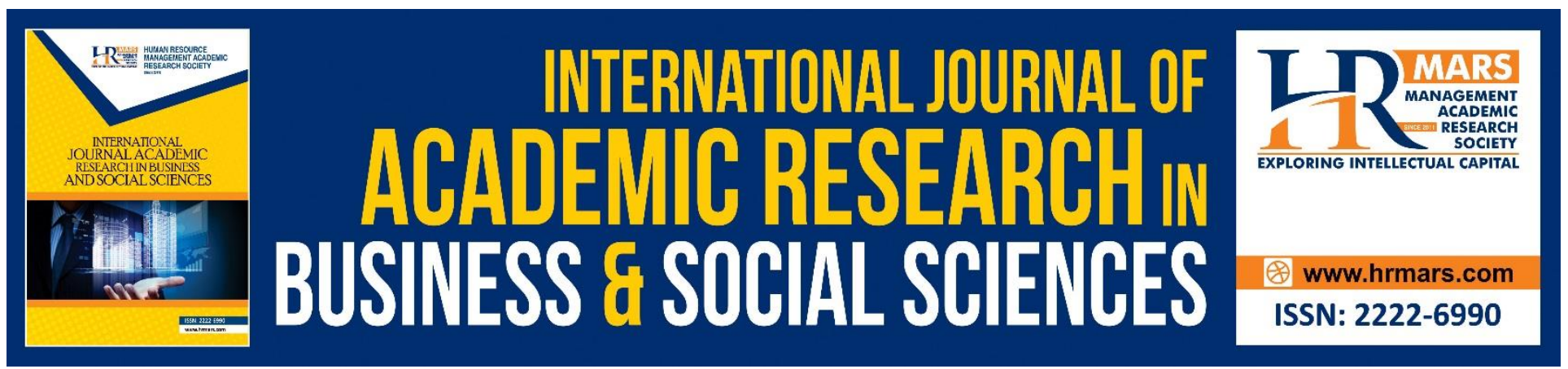

\title{
The Understanding of Mainstream Teachers on the Implementation of the Semi-Inclusive Program in the Curriculum for Special Education (Dyslexia)
}

\author{
Shahrul Rozaina Binti Jelani, Mohd Mokhtar Bin Muhamad, Umi \\ Kalthom Abdul Manaf \\ Fakulti Pengajian Pendidikan, Universiti Putra Malaysia \\ Email: ekal_syamil02@yahoo.com.my,mk_mokhtar@upm.edu.my,umizat90@upm.edu.my
}

\begin{abstract}
This study aimed to explore the understanding of mainstream teachers on the implementation of the Semi-Inclusive Program in the Curriculum for Special Education (Dyslexia) or the CSED. The rationale for the study is to examine its importance in improving the understanding of mainstream teachers about dyslexia and its impact on dyslexic students. The respondents of the study were four mainstream teachers, four special education teachers, and seven fifth-year dyslexic students from a school in Klang Valley. The findings from the interview data indicated that: 1) the mainstream teachers are still obscure in their understanding of the characteristics of dyslexic students and the CSED, and 2) the mainstream teachers have a mixture of positive and negative perceptions towards the dyslexic students. The research concluded that the mainstream teachers involved in the CSED should be specifically trained and educated on dyslexia and the CSED implementation.
\end{abstract}

Keywords: Mainstream Teachers, Semi-Inclusive Programs, Dyslexic Curriculum, Dyslexic Students.

\section{Introduction}

The Special Education Division, Ministry of Education (2015) in Malaysia stated that students with special needs should be given opportunities to receive relevant and appropriate educational access. Therefore, the Ministry of Education (MOE) has developed a special education curriculum applicable to all schools with special education programs including the Curriculum for Special Education (Dyslexia) or the CSED. In addition, an Inclusive Education Program was developed to assist students with special needs to be placed inclusively in the mainstream classes due to their potential to study along with their peers in the mainstream classes (Special Education Division, MOE, 2015). For dyslexic students, semi-inclusive education is implemented where certain subjects are taught along with mainstream students, in mainstream classrooms, by mainstream teachers. Even though dyslexic students are present, CSED still uses the mainstream curriculum with only minor modifications to match students with different academic levels. As suggested by Richardson (1996), the inclusion of 
children with dyslexia in a mainstream classroom should incorporate not only a modified curriculum and methods for teaching the basic skills but also mandating in-service training that provides knowledge of the structure of language for all teachers. For this reason, teachers involved in the CSED should have the understanding and knowledge of the curriculum being implemented and the problems experienced by dyslexic students. This understanding aims to ensure that educators will be able to provide accurate and useful knowledge and practice in implementing education for dyslexic students.

The Special Needs Education Program (SNEP) places students with special needs such as those with syndrome down, autism, cerebral palsy, dementia, and ADHD in one classroom. Even though dyslexic students are categorized under SNEP, they still have the ability to follow the mainstream syllabus. Therefore, it is more appropriate for dyslexic students to undertake the Standard Curriculum for Primary School 1 while the other students with special needs should fully undertake the Special Education Standard Curriculum2. According to the Curriculum Development Division, Ministry of Education Malaysia (2015), dyslexic students have a normal level of intelligence like other students and sometimes can surpass the intellectual of the mainstream students. However, they need to be assisted by special education teachers so that they can overcome their dyslexic difficulties.

The learning process of dyslexic students is more complicated in an inclusive classroom where they are being taught by mainstream teachers and learning alongside other mainstream students. According to a large-scale survey by Knight (2018), teachers in England and Wales are lack of knowledge on the biological and cognitive aspects of dyslexia. Another study in Turkey found similar results where teachers were not knowledgeable enough and not ready to teach students with dyslexia (Dodur \& Kumas, 2020). A longitudinal study found that task avoidance behaviour among dyslexic students significantly increased from Grade 2 to Grade 7 (Syal \& Torppa, 2019). These studies indicated that mainstream teachers are facing a unique challenge in teaching inclusive classrooms where both mainstream students and dyslexic students are present.

\section{Problem Statement}

According to Butler and Edmonson (2009), students with dyslexia can overcome difficulties related to dyslexia with the support and assistance of their teachers. There should be no problem if dyslexic students were taught by special education teachers. The current practice in an inclusive classroom for dyslexic students involves mainstream teachers teaching dyslexic students in certain subjects. The questions are: How do these dyslexic students learn with the mainstream teachers who were not educated to teach CSED students? Can the mainstream teachers understand the experience of these dyslexic students? How do the mainstream teachers help these dyslexic students in overcoming their dyslexic difficulties?

\section{Research Objectives}

To explore the understanding of mainstream teachers about dyslexic students.

To explore the understanding of mainstream teachers about the implementation of the CSED curriculum.

1 Translated from the Malay name for Kurikulum Standard Sekolah Rendah (KSSR).

2 Translated from the Malay name for Kurikulum Standard Sekolah Rendah Pendidikan Khas (KSSRPK). 
INTERNATIONAL JOURNAL OF ACADEMIC RESEARCH IN BUSINESS AND SOCIAL SCIENCES

Vol. 10, No. 10, 2020, E-ISSN: 2222-6990 @ 2020 HRMARS

To explore how the mainstream teacher manage the inclusive classroom with the presence of the dyslexic students.

\section{Research Questions}

- What are the understandings of the mainstream teachers have on the dyslexic students?

- What are the mainstream teachers' understandings of CSED implementation?

- How do the mainstream teachers manage the inclusive classroom with the presence of the dyslexic students?

\section{Literature Review}

Curriculum for Dyslexia in Malaysia. According to Allan and Persson (2018), students who follow inclusive programs have the opportunity to succeed in life. For them to attend a school that provides a good inclusive learning environment is a vehicle for all successful students. This is because students consider their relationship with the teacher to be the determining factor in their success. Therefore, the Special Education Division, MOE (2015) stated that students with special needs have the potential to be inclusively included in the mainstream classes. It is also a high-quality educational provision for students with disabilities throughout Malaysia. The dyslexic curriculum is a national curriculum that is modified based on the needs of students with dyslexia. All students who follow this curriculum will not be exempted from public examinations. All students with dyslexia will follow the preliminary flow curriculum with slight modifications to the level of pupil ability.

Learning Difficulties and Behavioral Issues. There are several difficulties that dyslexic students are facing as students in schools. First, they have difficulty with reading. They will usually read too fast to add or subtract a letter or a phrase in a word. They also tend to skip lines when reading especially for long texts. Davies et al. (2007) stated that children with dyslexia have a slower reading ability than their chronological age. Second, dyslexic students also have difficulties in writing and spelling. It is difficult for them to pronounce written words (phonological) and to write words. They tend to write in reverse, therefore unconsciously interchanging between the letters $b$ and $d, n$ and $u$, and $m$ and $w$. Third, dyslexic students have trouble remembering things because their memories are in the short term. It is difficult for them to process multiple information at the same time. These difficulties not only affect their academic performance but also results in behavioral issues in the classroom setting.

In general, we know that each student has their level of ability whether they are normal students or special education students. This also applies to dyslexic students. Although they are categorized by the MOE as students with high brain intelligence or similar to the mainstream students, they are still categorized as students with learning difficulties. Therefore, teachers' understanding is very important in helping their academic and personal development. According to Reid (2011), dyslexia is a term of many definitions with statements that do not mean much to parents and some educators. This is evident from the some studies in England, Wales, and Turkey which found that teachers are lack in their knowledge and understanding of dyslexia (Knight, 2018; Dodur \& Kumas, 2020).

Teacher's Understandings of CSED. As per the teachers' understanding of students with dyslexia in Malaysia, the mainstream teachers should know about the CSED. The curriculum applies to both the national and special education curricula. The national curriculum is modified according to the ability 
INTERNATIONAL JOURNAL OF ACADEMIC RESEARCH IN BUSINESS AND SOCIAL SCIENCES Vol. 10, No. 10, 2020, E-ISSN: 2222-6990 @ 2020 HRMARS

of students with dyslexia. Therefore, the curriculum is implemented through a Semi-Inclusive Education Program (SIEP). For this SIEP, mainstream teachers cannot deny the rights of dyslexic students in their classrooms. These students need to be guided equally as other students. However, teachers need to be aware of their needs as students with learning disabilities. Therefore, mainstream teachers need to accept their presence in the mainstream classroom and attend teaching and learning sessions with the other students. According to Hamdan and Anuar Hussin (2013), the positive perception of mainstream teachers towards SIEP is essential to assist students with special needs.

Furthermore, Amin and Yassin (2016) claimed that the knowledge of the current administration and teachers of SIEP is important in order to help SIEP to be properly and effectively implemented. Therefore, positive relationships between teachers and students are important because students with special needs tend to have low self-esteem (Saad, 2006). Teachers may not understand inclusiveness (Vaughn et al., 1994). Therefore, mainstream teachers involved in teaching students with special needs should be educated and equipped with knowledge on the concept of inclusive education. Vaughn et al., (1994) also found that the most consistent teacher's perception is high negative feelings towards inclusiveness.

\section{Research Methodology}

The qualitative study was conducted at a school in Klang Valley, Malaysia. This school was specifically selected because of its CSED implementation. Data was collected by interviewing four mainstream teachers who were teaching fifth-year students in inclusive classrooms with dyslexic students. In addition, four special education teachers were also interviewed. The special education teachers were trained in special education programs for dyslexia and were specifically assigned to teach students with special needs in the school. These data were collected through semi-structured interviews.

\section{Research Findings}

Findings from this research are divided into three categories, in line with the research question. First, the understandings of the mainstream teachers on the dyslexic students themselves. Second, The understanding of the mainstream teachers on the implementation of the CSED. Finally, the perceptions of the mainstream teachers on the presence of the dyslexic students in their classroom.

\section{The Understandings of The Mainstream Teachers on The Dyslexic Students}

The interview analysis found that the mainstream teachers did not describe dyslexia students as students with certain difficulties in reading, writing, spelling, or remembering as described in the literature. The mainstream teachers used words such as "aggressive," "hyperactive," and "weird" in describing the dyslexic students. These are some of the responses from the mainstream teachers: "Aaa...there are two responses if that aggressive students, there can be two responses. At times the students will act aggressively if in anger. Throwing things. Number two, he will be quiet, become hard like a stone." (MT1)

"Some students, when the weather is hot, he cannot stand it. Making noises. He will scream...making the class chaotic." (MT2)

"Some are hyperactive...Sometimes, these dyslexic students have weird attitude. Weird attitude that we cannot handle because we are not exposed to courses [on educating dyslexic students]." (MT4) 
INTERNATIONAL JOURNAL OF ACADEMIC RESEARCH IN BUSINESS AND SOCIAL SCIENCES Vol. 10, No. 10, 2020, E-ISSN: 2222-6990 @ 2020 HRMARS

Only one mainstream teacher described a characteristic of dyslexic students in terms of difficulty in writing. However, the description is in a negative perception:

"But when they sent err... writing paper works, then you know that their writings are really bad." (MT4).

However, mainstream teachers do not have only negative perceptions. They also have positive perceptions towards the dyslexic students. These are some of the positive remarks they gave in describing dyslexic students:

"Almost all dyslexic students live music...that is an advantage. For example, a dyslexic student who really good in music, a student I met. A student, he is intelligent. Only a little bit [of explanation], he will understand... what will happen after this, what to do next..." (MT1)

"But there is one aspect that they are outstanding. For example, previously I have a [dyslexic] student... at that time he was in fifth year...aaa... his mathematics was really great!" (MT2)

\section{The Understanding of CSED Implementation by the Mainstream Teachers}

Based on the analysis of the transcribed interviews, it was found that the understanding of the mainstream teachers on the implementation of CSED is still unclear and obscure. All mainstream teachers interviewed expressed uncertainty about the partial SIEP implemented in the school's special education (dyslexia) curriculum when asked about the Inclusive Education Program. These are some of the responses by the mainstream teachers on the implementation of CSED:

"I actually want to skip this question. Firstly...l...aaa...I received the complete information...but...I cannot elaborate till the end...I did not finished reading it yet...I cannot say more, I might make some mistake." (MT1)

"Ermmm...No...semi-inclusive...Actually, I don't really know inclusive itself." (MT2)

"I am not sure inclusive, full..." (MT3)

The only implementation that one of the mainstream teachers understands is the separation of dyslexic students from mainstream students when certain subjects are being taught:

"They will be separated [from the mainstream class] and go to their own class. From the mainstream class, to the [specific class for dyslexia students]." (MT2)

From the interview with special education teachers, one of the teachers claimed that the CSED is not being implemented:

"I don't think it is being implemented. They leave this responsibility to the special education teachers because...there was one time I went to their classroom...they [the dyslexic students] were doing their own works. Maybe they don't care." (SET 3).

According to UNESCO (2001) in the Open File of Inclusive Education, it is dangerous if SIEP is not managed properly because teachers will have the tendency to isolate students with special needs and this will cause these students to lose their interest in an inclusive learning session, whereas, SIEP should be one of the best programs designed to help students with disabilities to acquire good quality education.

\section{The Mainstream Teachers and The Presence of The Dyslexic Students}

The interview analysis indicated that mainstream teachers have a mixture of positive and negative feedback on the presence of the dyslexic students in their classrooms. These are some of the positive feedbacks: 
INTERNATIONAL JOURNAL OF ACADEMIC RESEARCH IN BUSINESS AND SOCIAL SCIENCES Vol. 10, No. 10, 2020, E-ISSN: 2222-6990 @ 2020 HRMARS

"Helpful. For me, it is helpful. We live in a community. Whether you like it or not, you have to accept the situation. For me, the students is the situation...they learn. Along with the teacher." (MT1) "Usually, I made the dyslexic students as examples... as a standard...if the dyslexic student is weak, I will make him as a standard for other students to follow. Not to downgrade him but he was also excited. For example, in music when other students were not listening, for example, playing percussions, playing tambourine, for example. Other students cannot do it, or were not serious, I will call him "Look at him (the dyslexic student), he can play. Even he can play. But you cannot?"'” (MT1). "There are some other students who have negative perceptions towards them. Saying that they are weak. Whereas, they have talents." (MT4)

However, some mainstream teachers felt that the presence of the dyslexic students in the mainstream classes is problematic for the teaching and learning process:

"For me, there are good times, there are bad times. Good example, in terms of mixing with others, they are good. But in terms of important subjects...no subjects...all subjects... when we are serious in learning...aaa...there will be problems." (MT1)

"Aaa...it is not a big problem mixing them together, chatting, befriending and all...it's just the... the [dyslexic students] have a little bit of childish attitude. Their maturity is not [at the same level] as other students." (MT2)

One of the mainstream teachers even agreed with other students' opinion that the dyslexic students should be excluded from the mainstream classroom:

"Sometimes aaa...normal students attitude... [The mainstream students] feel that the [dyslexic] students are weak. Weak, but in physical education, playing together is normal. But in learning, they feel that the [dyslexic] students are weak. So...they want to exclude them...from teacher's opinion too." (MT4)

Another negative perception by the mainstream teacher stated that dyslexic students "bullied" other students including some teachers:

"Some are quiet, some are active...so, the quiet ones maybe we don't have problem with. The active ones are the ones that bullied other students... we have to know which students we should pay more attention to. Cannot simply let them be. He...sometimes students there, [it depends on] the teachers too...there are teachers that they can bully." (MT4)

Finally, the interview analysis also indicated the importance of giving special attention to dyslexic students learning in mainstream classrooms. Some response from the mainstream teachers specifically mentioned the importance of giving extra attention to the dyslexic students and not locating too many dyslexic students in a mainstream classroom:

"I think they need more attention." (MT3)

"Err...dyslexic students are not supposed to...in the fifth-year classroom right now...there are nine dyslexic students, my own class. For me, this is too many. Because they require special attention from the teacher." (MT4)

The experience of the mainstream teachers regarding the need for special attention among dyslexic students leads to the issue of classroom management. Both mainstream teachers and special education teachers agreed that the dyslexic students should be positioned in the front rows of the classroom so that teachers can provide special attention to them.

"In the classroom...Aha...yes. In groups, they should sit in the front groups. If in line, they should is the front row." (MT2) 
INTERNATIONAL JOURNAL OF ACADEMIC RESEARCH IN BUSINESS AND SOCIAL SCIENCES Vol. 10, No. 10, 2020, E-ISSN: 2222-6990 @ 2020 HRMARS

"If they want to enter the mainstream class... make them serious such as sit on the front rows. They cannot sit on the back rows. Have to give them the opportunity to sit on the the front rows." (MT3) "...when in the meeting, we said, dyslexic students should be seated on the front rows. We told to the school administrations. It is in the meeting minute....there are still teachers who did not comply because the dyslexic students were sitting on the back rows." (SET2)

"Errr...some classrooms placed the dyslexic students on the front rows...but there are classes where they were on the back rows. That is what I disagree." (SET 2).

According to Reid (2011), in the context of learning, a teacher needs to identify and assess a student's level of difficulty in learning. Learning abilities depend on learning styles that make it easier for a certain group of students to minimize their problems in learning. Therefore, it is important for the mainstream teachers involved in teaching dyslexic students in an inclusive classroom to understand the learning styles of dyslexic students and take specific measures in minimizing their learning difficulties.

\section{Discussions and Conclusion}

The interview analysis indicated several important findings which can be the initial stage in improving our knowledge of the state of the inclusive classroom for students with dyslexia in the particular school studied. First, the understanding of the mainstream teachers on the implementation of CSED is still unclear and obscure. Based on the previous studies and literature reviews, teachers' understanding is very important in helping dyslexic students, especially the understanding of mainstream teachers involved in teaching such students. This is because they are not specifically trained to teach students with dyslexia. This possibly leads to the second finding concerning their misunderstandings of the difficulties of dyslexic students. They described them as having behavioural problems and not as students with special needs due to their specific difficulties in reading, writing, spelling, and remembering. The mainstream teachers used words such as "aggressive," "hyperactive," and "weird" in describing the dyslexic students. Some mainstream teachers felt that the presence of the dyslexic students in the mainstream classes is problematic for the teaching and learning process and even suggest that the dyslexic students should be excluded from the mainstream classroom. Leseyane et al. (2018) also found a similar attitude among public school teachers in South Africa where they did not have patients, did not give extra attention and even used negative comments that embarrassed students with dyslexia.

However, the mainstream teachers in this study did not have only negative perceptions, rather they also expressed positive perceptions towards students with dyslexia in certain ways such as having talents that the mainstream students do not have. Therefore, we conclude that the mainstream teachers in the school generally have mixed attitudes towards the dyslexic students. As teachers, they still have the passion to teach without discriminating against any type of student. On the other hand, they seem confused and struggling in dealing with inclusive classrooms where dyslexic students are present in the process of teaching and learning. This finding is in line with Woodcock and Hitches (2017) as they found a more negative attributional outcome towards students with a specific learning disability compared to students without learning disability.

Finally, the mainstream teachers as well as the special education teachers also addressed some important strategies in conducting inclusive classrooms. Some mainstream teachers suggested giving extra attention to the dyslexic students and not locating too many dyslexic students in a mainstream classroom. Both mainstream and special education teachers agreed that the dyslexic students should 
INTERNATIONAL JOURNAL OF ACADEMIC RESEARCH IN BUSINESS AND SOCIAL SCIENCES Vol. 10, No. 10, 2020, E-ISSN: 2222-6990 @ 2020 HRMARS

be positioned in the front rows of the classroom so that teachers can provide them with special attention. However, none of the teachers addressed any specific intervention found from research literature such as using combined instructional strategies with narrative texts (Awada \& GutierrezColon, 2017), multi-sensory strategies (Mills, 2018), or the writing therapy in increasing confidence and self-esteem among dyslexic students (Laranjeira et al., 2019). Perhaps, the CSED requires specific strategies and explanations based on empirical evidence on what are the minor modifications required to match students with different academic levels.

From an overall perspective, this issue should not only be addressed from the administrators and policy-makers perspective in executing certain curriculum policies such as making a classroom inclusive or providing training for mainstream teachers on how to teach students with dyslexia. For example, Rahman and Woollard (2019) addressed the problem from the perspective of remediation framework versus neurodiversity framework. The remediation framework aims on identifying causes of difficulties while the neurodiversity framework aims at accommodating diverse ways of learning. Based on their findings, Rahman and Woollard (2019) concluded that the teachers exhibit a good understanding of the remediation framework where they perceive students with dyslexia as "problems that need to be fixed." What should be inculcated among the mainstream teachers is the neurodiversity framework where dyslexia are considered as a segment of learning diversity we already have.

This study indicated that even though inclusive classrooms for dyslexia students theoretically helping dyslexic students in fulfilling their educational needs, its implementation requires firm understanding from the teachers involved. Without proper understanding, there is a possibility that inclusive classroom can damage the educational experiences of the dyslexic students as demonstrated in this study. In the context of this study, understanding on the concept of dyslexia and classroom management strategies are both important. Without proper understanding on dyslexia and its nature, it will be difficult for the mainstream teachers to properly manage the inclusive classroom. Further studies are suggested to explore and design the best method for mainstream teachers to be educated and trained in implementing the CSED. Therefore, the findings of this study are hoped to assist mainstream teachers and educational administrators regarding the importance of understanding and knowledge in implementing the CSED among mainstream teachers.

\section{References}

Allan, J., \& Persson, E. (2018). Social capital and trust for inclusion in school and society, 1-11. https://doi.org/10.1177/1746197918801001

Amin, N. M., \& Yasin, M. H. M. (2016). Pelaksanaan program pendidikan inklusif murid berkeperluan khas dalam Pelan Pembangunan Pendidikan Malaysia 2013 -2015. International Conference on Special Education in Southeast Asia, (January), 28-35.

Awada, G. M., \& Gutierrez-Colon, M. (2017). Effect of Inclusion Versus Segregation on Reading Comprehension of EFL Learners with Dyslexia: Case of Lebanon. English Language Teaching, 10(9), 49. https://doi.org/10.5539/elt.v10n9p49

Bahagian Pendidikan Khas, MOE. (2016). Panduan Perlaksanaan Pedagogi Inklusif (Cetakan Pertama). Nur Maju Resources.

Bahagian Pendidikan Khas. MOE. (1996). Kod Amalan Pendidikan Murid Berkeperluan Khas. Utusan Print Corp Sdn. Bhd. 
INTERNATIONAL JOURNAL OF ACADEMIC RESEARCH IN BUSINESS AND SOCIAL SCIENCES Vol. 10, No. 10, 2020, E-ISSN: 2222-6990 @ 2020 HRMARS

Bahagian Pendidikan Khas. MOE. (2013). Garis Panduan Program Pendidikan Inklusif Murid Berkeperluan Khas. Edisi Percubaan, 21. Ministry of Education Malaysia. http://moe.gov.my/images/Bahagian-pendidikan-khas/Program-Pendidikaninklusif/circularfile_file_001162.pdf

Butler, C., \& Edmonson, S. L. (2009). Fostering Resiliency: Making Schools a Better Place for Students with Dyslexia. In Pro Active Publications (Ed.), REMEMBER OUR MISSION: Making Education and Schools Better for Students: THE 2009 YEARBOOK OF THE NATIONAL COUNCIL OF PROFESSORS OF EDUCATIONAL ADMINISTRATION. DEStech Publications, Inc.

Davies, R., Cuetos, F., \& Glez-seijas, R. M. (2007). Reading development and dyslexia in a transparent orthography : a survey of Spanish children. The International Dyslexia Association 2007, 57, 179-198. https://doi.org/10.1007/s11881-007-0010-1

Hamdan, A. R., \& Anuar Hussin, M. K. (2013). Persepsi Guru Aliran Perdana Terhadap Inklusif. In 2nd International Seminar on Quality and Affordable Education (ISQAE 2013) (pp. 265-270).

Kementerian Pendidikan Malaysia. (2015). Buku Panduan Pengoperasian SNEP. Bahagian Pendidikan Khas, MOE, 188.

Knight, C. (2018). What is dyslexia? An exploration of the relationship between teachers' understandings of dyslexia and their training experiences. Dyslexia, 24(3), 207-219. https://doi.org/10.1002/dys.1593

Laranjeira, T., Casal, J., \& Picado, L. (2019). The Contributions of Writing Therapy among Dyslexic Students. American Research Journal of Humanities \& Social Science, 2(7), 13-20.

Leseyane, M., Mandende, P., Makgato, M., \& Cekiso, M. (2018). Dyslexic learners' experiences with their peers and teachers in special and mainstream primary schools in North-West Province. African Journal of Disability, 7. https://doi.org/10.4102/ajod.v7i0.363

Mills, J. R. (2018). Effective Multi-Sensory Strategies for Students With Dyslexia. Kappa Delta Pi Record, 54(1), 36-40. https://doi.org/10.1080/00228958.2018.1407181

Ornstein, A. C., \& Hunkins, F. P. (1988). Curriculum: Foundations, Principles, and Issues (1st ed.) Prentice Hall

Rahman, A. A., \& Woollard, J. (2019). Neurodiversity awareness: Is Malaysia there yet? International Journal of Evaluation and Research in Education (IJERE), 8(4), 676. https://doi.org/10.11591/ijere.v8i4.20307

Reid, G. (2011). Dyslexia: A Complete Guide for Parents and Those Who Help Them (Second). John Wiley \& Sons.

Richardson, S. O. (1996). Coping with dyslexia in the regular classroom: Inclusion or exclusion. Annals of Dyslexia, 46(1), 37-48. https://doi.org/10.1007/BF02648170

Supiah, S. (2006). Komitmen dan Peranan Guru dalam Perlaksanaan Pendekatan Pendidikan Inklusif di Malaysia. Journal of Special Education in the Asia Pacific (JSEAP), 2, 1-10.

Syal, S., \& Torppa, M. (2019). Task-avoidant behaviour and dyslexia: A follow-up from Grade 2 to age 20. Dyslexia, 25(4), 374-389. https://doi.org/10.1002/dys.1627

Unesco, \& United Nations Educational Scientific and Cultural Organization. (2015). Education for All 2000-2015: Achievements and Challenges. EFA Global Monitoring Report.

UNESCO. (2001). Open File on Inclusive Education. France: UNESCO: Devision of Basic Education.

Vaughn, S., Shay-Schumm, J., Jallad, B., Slusher, J., \& Saumell, J. (1994). Teachers' Views of Inclusion. Miami, FL: University of Miami.

Woodcock, S., \& Hitches, E. (2017). Potential or problem? An investigation of secondary school 
INTERNATIONAL JOURNAL OF ACADEMIC RESEARCH IN BUSINESS AND SOCIAL SCIENCES

Vol. 10, No. 10, 2020, E-ISSN: $2222-6990$ @ 2020 HRMARS

teachers' attributions of the educational outcomes of students with specific learning difficulties. Annals of Dyslexia, 67(3), 299-317. https://doi.org/10.1007/s11881-017-0145-7 